\title{
Gain scheduling control applied to oil and gas separator level loop
}

\author{
Controle adaptativo tipo gain scheduling aplicado ao controle de nível de vaso separador de \\ petróleo e gás natural
}

Control adaptativo tipo gain scheduling aplicado al control de nivel del separador de petróleo y gas natural

Received: 03/29/2021 | Reviewed: 04/08/2021 | Accept: 04/11/2021 | Published: 04/23/2021

Márcio Lindemberg Bezerra de Medeiros
ORCID: https://orcid.org/0000-0001-9199-5899
Federal University of Sergipe, Brazil
E-mail: marcio@geofex.com.br
Antonio Martins de Oliveira Junior
ORCID: https://orcid.org/0000-0002-8635-7048
Federal University of Sergipe, Brazil
E-mail: amartins@academico.ufs.br
Rodolpho Rodrigues Fonseca
ORCID: https://orcid.org/0000-0002-5831-7460
Federal University of Sergipe, Brazil
E-mail: rodolphorf@academico.ufs.br

\begin{abstract}
Modeling and simulation applied to level control of oil and gas separators in production facilities is a very important tool because makes possible to perform tests that probably could not be viable due to operation and safety constraints. Asides the level dynamics can be well understood regarding the physical model, there will always be non-linearities to approach using a system identification procedure, requiring reasonable care on linear model identification. In order to assure a desired control performance, an adaptive control strategy has been proposed for level control for an oil and gas separator using the gain scheduling technique. Based on a first order process without time delay, the static gain and time period were determined for each point inside the operational space range of the equipment and by Internal Model Control (IMC), the tuning matrix found and converted into a function of operational parameters using polynomial interpolation methodology for future application in a real commercial PI controller. The horizontal separator was simulated using MATLAB/SIMULINK ${ }^{\circledR}$ and data from a real separator vessel were used to identify and validate the proposed process modeling in attempt to test an adaptive control strategy for practical applications. Once the GSC was implemented, simulations were performed over the non-linear system and results have shown better performance indexes for GSC while compared to the conventional PI controller for both servo and regulatory problems with reductions up to $17.65 \%$ for IAE, $29.88 \%$ for ISE, $16.38 \%$ for ITAE, $29.00 \%$ for ITSE and $13.20 \%$ for Control Effort (CE).
\end{abstract}

Keywords: Modeling; Adaptive level control; Oil; Gas separator.

\section{Resumo}

Os conceitos de modelagem e simulação aplicados ao controle de nível em processamento primário de petróleo e gás constituem uma ferramenta de grande importância por permitirem a realização de testes que provavelmente não poderiam ser viáveis devido a restrições operacionais e de segurança. Embora a dinâmica do nível seja bem conhecida do ponto de vista físico, sempre haverá não-linearidades inerentes que deverão ser verificadas mediante a realização de procedimento de identificação de modelo, necessitando razoável precaução na aplicação de ferramentas de modelo linear. De modo a garantir o desempenho desejado, uma estratégia de controle adaptativo foi proposta para realizar o controle de nível de um separador de petróleo e gás natural usando a técnica Gain Scheduling Control (GSC). Tomando por base o modelo de um processo de primeira ordem (First Order Process - FOP) sem tempo morto, os ganhos estáticos e constantes de tempo foram determinados para cada ponto pertencente a faixa (range) operacional do equipamento e, pelo método de sintonia IMC, encontrada a matriz de sintonia para um controlador do tipo PI, implementado em um controlador PI comercial usando-se a metodologia de interpolação polinomial. O separador horizontal bifásico foi simulado utilizando-se o pacote computacional MATLAB/SIMULINK® e dados de processo de um vaso separador em planta real foi usado para identificar e validar a modelagem proposta em um esforço de testar a estratégia de controle adaptativo para aplicações práticas. Por simulação do modelo não linear, foi possível confirmar, através de índices de qualidade, melhor desempenho do controlador GSC comparado a um controlador PI convencional tanto para o problema servo quanto para o problema regulatório com redução de até $17,65 \%$ no índice IAE, 29,88\% no índice ISE, 16,38\% no índice ITAE, 29,00\% no índice ITSE e 13,20\% no esforço de controle (CE). 
Palavras-chave: Modelagem; Controle de nível adaptativo; Separador de petróleo; Gás.

\begin{abstract}
Resumen
Los conceptos de modelado y simulación aplicados al control de nivel en procesamiento primario de petróleo y gas constituyen una herramienta de gran importancia por permitir la realización de pruebas que probablemente no podrían ser viables debido a restricciones operacionales y de seguridad. Aunque la dinámica del nivel es bien conocida desde el punto de vista físico, siempre habrá no linealidades inherentes que deberán ser verificadas mediante la realización de procedimiento de identificación de modelo, necesitando razonable precaución en la aplicación de herramientas de modelo lineal. Con el fin de garantizar el rendimiento deseado, se propuso una estrategia de control adaptativo para realizar el control de nivel de un separador de petróleo y gas natural utilizando la técnica Gain Scheduling Control (GSC). Tomando como base el modelo de un proceso de primer orden (First Order Process - FOP) sin tiempo muerto, las ganancias estáticas y constantes de tiempo fueron determinadas para cada punto perteneciente al rango (range) operacional del equipo y, por el método de sintonía IMC, encontrada la matriz de sintonía para un controlador de tipo PI, implementado en un controlador PI comercial utilizando la metodología de interpolación polinómica. El separador horizontal bifásico se ha simulado utilizando si el paquete computacional MATLAB/SIMULINK® y datos de proceso de un vaso separador en planta real fue utilizado para identificar y validar el modelado propuesto en un esfuerzo de probar la estrategia de control adaptativo para aplicaciones prácticas. Por simulación del modelo no lineal, fue posible confirmar, a través de índices de calidad, mejor desempeño del controlador GSC comparado a un controlador PI convencional tanto para el problema servo como para el problema regulatorio con reducción de hasta 17,65\% en el índice IAE, 29,88\% en el índice ISE, 16,38\% en el índice ITAE, 29,00\% en el índice ITSE y 13,20\% en esfuerzo de control (CE).
\end{abstract}

Palabras clave: Modelado; Control de nivel adaptativo; Separador de petróleo; Gas.

\title{
1. Introduction
}

Oil, gas and water are present in all hydrocarbon reservoirs under thermodynamics equilibrium. This equilibrium is broken when the reservoir is depressurized to get its fluids up to the surface, operation this known as production. Fluids need to reach surface through the production string and at surface they are conducted by pipeline to the production headers and manifolds where liquid and gas from many wells can be mixed all together in a unique stream and driven onto production facility. In the first stage separator, after retention time, decanting, and stabilization of pressure and level, oil, gas and water leave the separator in separated lines. The thermodynamic analysis of the separation process is widely discussed and can be found elsewhere (Sayda \& Taylor, 2007).

All crude oil processing requires process variables (PV) to be controlled, e.g. pressure and liquid level,. This control is mostly implemented using proportional integral derivative (PID) controllers as part of a programmable logical controller (PLC) instructions in order to keep the PV inside an acceptable range centered by a desired value, defined as set point (SP), trying to minimize the error. Quite often one may find operational teams not very familiar with control theory, leading to control parameters set based only on the practical experience, resulting in not interests nor encouragement for control loop upgrade. However, this situation brings up great opportunity of improvements with minor modifications (John-Morten, Stig \& Gunleiv, 2005).

Tuning analysis should be the first attempt while aiming better control performance. As example, in order to overcome slugging problems in offshore three-phase inlet separator, Zhenyu, Michael, and Løhndorf (2010) had proposed a simplified approach to a conventional PI controller of the level loop working on enhanced tuning procedures such as trial-and-error method, Butterworth filter design method and IMC method getting satisfactory results.

The development of adaptive control strategies for liquid level regulation in a set of two coupled tanks were the object of research of many papers. Some authors have compared three different types of adaptive controller, i. e. a direct model reference adaptive controller MRAC, an indirect MRAC with Lyapunov estimation, and an indirect MRAC with recursive least-squares (RLS) updating estimation for liquid level control (David \& Lei, 2005), being the best results obtained using RLS estimation. On the other hand, other authors used Adaptive Fuzzy Control strategy, which consists of a model identifier and controller (Basçi \& Derdiyok, 2016). Results of such technique showed better setpoint tracking performance than PI controller for plant transient 
responses. Other works with similar objectives can be found in (Giovani, 2004), (Suryawanshi, Chandrashekhar \& Virendra, 2007), (Leosirikul, Chilin, Liu, Davis \& Christofides, 2011), (Sausen, Sausen, Reimbold \& Campos, 2012), (Sundaram, 2013), (Zaher, 2018).

Among several manners of adaptation there is the Gain Scheduling. The controller projected that way has been named Gain Scheduling Controller (GSC). Bagyaveereswaran and Arulmozhivarman (2019) worked with Gain Scheduling to develop a RTD-A controller, where RTD-A stands for Robustness, setpoint Tracking, Disturb rejection and overall Aggressiveness). They have analyzed three industrial application model including a conical shape tank. In the same thematic, Vikhe, Parvat and Kadu (2019) have applied GSC in a more concise form for a variable cross sectional area tank. They have realized integral time be independent of the tank parameters and, differently, the proportional gain be directly related to the cross sectional area (scheduling variable) to each value of stationary level. More references about the Gain Scheduling application are present in (Bisowarno, Tian \& TADÉ, 2003), (Fernandes, Moraes, Paulo \& Oliveira, 2013), (Onat, 2014), (Ban \& Wu, 2015), (Gao \& Lakerveld, 2019), (Sarkar \& Banerjee, 2019).

Thus, considering the non-linearities of level dynamics in a real horizontal cylindrical separator, this article proposes a non-linear control technique for level regulation using an adaptive gain scheduling PI controller and a control valve with exponential curve feature. Materials and methods are covered in section 2 which presents the mathematical model development, followed by its linearization and implementation in a simulation. Section 3 ends the article validating an actual data set to the model and performing a study case comparing a standard PI controller tuned by IMC method to the gain scheduling controller (GSC) using performance criteria as integral of absolute error (IAE), Integral Square Error (ISE), Integral Time-weighted Absolute Error (ITAE), Integral Time-weighted Square Error (ITSE) and control effort (CE).

\section{Methodology}

The methodology proposed in this article is according to Koche (2011).

\subsection{Horizontal separators}

Production facilities widely uses horizontal separators because they can process more efficiently larger volumes of gas, and they are less expensive when compared with vertical or spherical separators for a similar dimension and gas capacity (Arnold, \& Stwart, 2010). To analyze the level dynamics, it is necessary to find the relationship among level rate of change and others operational conditions and geometrical relations in the horizontal separator. The process model development hereafter used is according to Zhenyu, Michael, and Løhndorf (2010), Sundaram (2013), Giovani, Medeiros, and Araújo (2010), Seborg, Edgar, Mellichamp and Doyle (2011).

\subsection{Process modeling}

From basic trigonometric rules, the volume of liquid inside the vessel indicated in Figure 1 can be found as a function of the liquid level $\mathrm{h}$ and vessel diameter D, represented in Equation 1. 
Figure 1 - Geometrical relations in the horizontal separator.

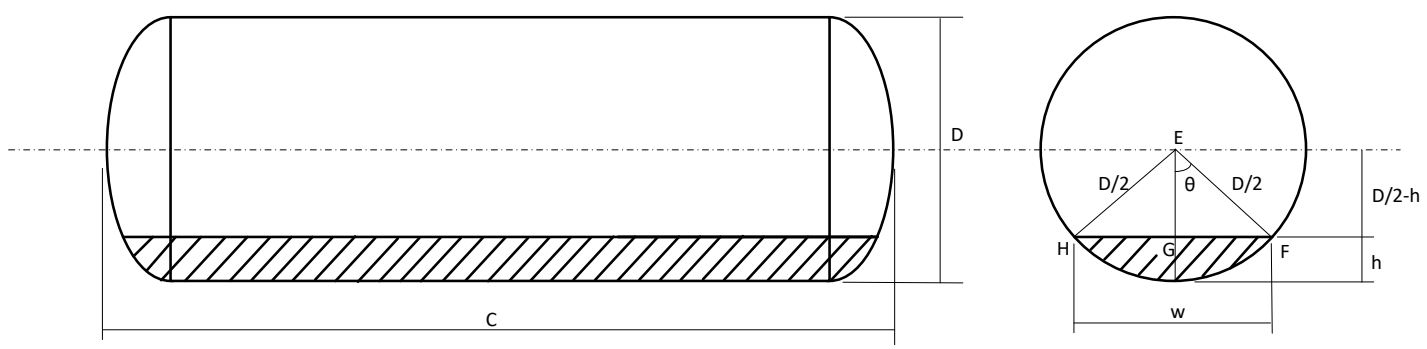

Source: Authors.

$V_{L}=C \times A=\frac{C D^{2}}{4}\left[\arccos \left(\frac{D-2 h}{D}\right)-\left(2 \frac{\sqrt{(D-h) h}}{D}\right)\left(\frac{D-2 h}{D}\right)\right]$

In this paper, the liquid is considered to be incompressible, which means that its specific mass $\left(\rho_{L}\right)$ is constant and the liquid mass rate can be determined using Equation 2, and applying the chain rule, the liquid volume rate is calculated as indicated in Equation 3.

$\frac{d M_{L}(t)}{d t}=\rho_{L} \frac{d V_{L}}{d t}$

and, applying the chain rule

$$
\frac{d V_{L}}{d t}=\frac{d V_{L}}{d \theta} \frac{d \theta}{d h} \frac{d h}{d t}
$$

Thus, one can easily find using Equations 1 to 3 the fundamental relationship between the rate of level change to the difference between the inlet and the outlet flow rate, represented by Equation 4. As expected, the liquid level has a nonlinear dynamic in horizontal separators, which requires an adaptive control strategy to better regulate the liquid level.

$\frac{d h}{d t}=\frac{L_{\text {in }}-L_{\text {out }}}{2 C \sqrt{(D-h) h}}$

In oil and gas facilities, the most common final control element is electro-pneumatic control valve. Considering a quick opening feature (Giovani, Medeiros \& Araújo, 2010), the volumetric flow rate $L_{\text {out }}$ can be calculated using Equation 5.

$L_{\text {out }}(t)=2,4028 \times 10^{-4} e^{x_{L}} C_{v} \sqrt{\frac{\Delta P}{\rho_{f}}}$

The volumetric flow rate $L_{\text {out }}$ is calculated considering the flow coefficient $\left(C_{v}\right)$, the valve opening position $\left(x_{L}\right)$, the pressure drop $(\Delta P)$ through the valve in bar, the relative density $\left(\rho_{f}\right)$ of the fluid at a specific temperature.

The standard PI controller finalizes the model. GSC has the same control law however, instead of fixed values for the parameters, the proportional gain $K_{p}$ and the integral time $T_{i}$ adapt themselves according to the operational conditions of the equipment. The error signal $e(t)$ have been normalized to values between $0-1$ as well as the valve position $x_{L}$. 


\subsection{Differential-algebraic model system}

Mathematically, the modeling discussed above can be represented as a non-linear differential-algebraic system stated in the Table 1.

Table 1 - Model of differential-algebraic system.

\begin{tabular}{|c|c|c|}
\hline Equation & Input & Output \\
\hline$L_{\text {out }}(t)=2,4028 \times 10^{-4} e^{x_{L}} C_{v}$ & $x_{L}[0-1]$ & $L_{\text {out }}(t)\left[\frac{m^{3}}{s}\right.$ \\
\hline$x_{L}=\left[K_{p} e(t)+\frac{K_{p}}{T_{i}} \int_{0}^{t} e(t) d t\right]$ & $\begin{array}{c}e(t)=(S P-h) \times \text { action } \times K_{\text {range }}[\mathrm{m}] \\
\text { action }=1(\text { direct }),-1(\text { indirect }) \\
K_{\text {rangeL }}=\frac{1}{(U R V-L R V)} \\
K_{p}, T_{i}\end{array}$ & $x_{L}[0-1]$ \\
\hline$\frac{d h}{d t}=\frac{L_{\text {in }}-L_{\text {out }}}{2 C \sqrt{(D-h) h}}$ & $L_{\text {in }}\left[\frac{m^{3}}{s}\right]$ & $h[m]$ \\
\hline
\end{tabular}

Source: Authors.

Model above involves an algebraic loop and require some care during implementation. Under proper initial conditions the system can be solved using MATLAB/SIMULINK ode45 (Dormand-Prince) solver. The system must be properly conditioned, capturing, for example, that $h$, as integrator output, is a state variable of the system. Secondly, inputs must be in accordance. For instance, for a given $\overline{L_{l n}}$, a corresponding $\overline{x_{L}}$ is expected. Non-linear model will be simulated with GSC designed in this work. Non-linear system implemented in SIMULINK can be seen in APPENDIX A.

For GSC design, the equations in Table 1 must be linearized, combined and using Laplace's Transformation converted into the transfer function representation for PI control tuning using IMC method.

Expanding Equation 4 in a Taylor's series, not accounting for the second and higher order terms and defining deviation variables, one can find its linear and deviated form $\left(f^{\prime}\right)$ stated in Equation 6.

$f^{\prime}=\frac{\partial f}{\partial h} h^{\prime}+\frac{\partial f}{\partial L_{\text {in }}} L_{\text {in }}^{\prime}+\frac{\partial f}{\partial L_{\text {out }}} L_{\text {out }}^{\prime}$

Applying the same methodology for Equation 5, the flow rate through control valve can be represented by its linear and deviated form in Equation 7.

$$
L_{\text {out }}^{\prime}=\frac{\partial L_{\text {out }}}{\partial x_{L}} x_{L}{ }^{\prime}+\frac{\partial L_{\text {out }}}{\partial P} P^{\prime}+\frac{\partial L_{\text {out }}}{\partial h} h^{\prime}
$$

Replacing Equation 7 in 6 and applying Laplace's transformation, the Equation 8 is obtained in terms of liquid level, valve control opening, pressure and inlet flow rate.

$H^{\prime}(s) s=\frac{\partial f}{\partial h} H^{\prime}(s)+\frac{\partial f}{\partial L_{\text {in }}} L_{\text {in }}^{\prime}(s)+\frac{\partial f}{\partial L_{\text {out }}}\left(\frac{\partial L_{\text {out }}}{\partial x_{L}} X_{L}^{\prime}(s)+\frac{\partial L_{\text {out }}}{\partial P} P^{\prime}(s)+\frac{\partial L_{\text {out }}}{\partial h_{L}} H^{\prime}(s)\right)$

Starting from Equation 8 one can find the model transfer functions (TF) as stated in Table 2, along with its respective derivatives in Table 3 . 
Table 2 - Function Transfer related to the process model.

\begin{tabular}{c|c|c} 
TF & Process Gain & Time Constant \\
\hline$G_{1}(s)=\frac{H^{\prime}(s)}{L^{\prime}{ }_{\text {in }}(s)}=\frac{K_{p 1}}{\tau_{p 1} s+1}$ & $K_{p 1}=\frac{-\frac{\partial f}{\partial L_{\text {in }}}}{\frac{\partial f}{\partial h}+\frac{\partial f}{\partial L_{\text {out }}} \frac{\partial L_{\text {out }}}{\partial h_{L}}}$ & $\begin{array}{c}\tau_{p 1} \\
\frac{\partial f}{\partial h}+\frac{\partial f}{\partial L_{\text {out }}} \frac{\partial L_{\text {out }}}{\partial h_{L}}\end{array}$ \\
\hline$G_{2}(s)=\frac{H^{\prime}(s)}{X^{\prime}{ }_{L}(s)}=\frac{K_{p 2}}{\tau_{p 2} s+1}$ & $K_{p 2}=\frac{-\frac{\partial f}{\partial L_{\text {out }}} \frac{\partial L_{\text {out }}}{\partial x_{L}}}{\frac{\partial f}{\partial h}+\frac{\partial f}{\partial L_{\text {out }}} \frac{\partial L_{\text {out }}}{\partial h_{L}}}$ & \\
\hline$G_{3}(s)=\frac{H_{p 2}=\tau_{p 1}}{P^{\prime}(s)}=\frac{K_{p 3}}{\tau_{p 3} s+1}$ & $K_{p 3}=\frac{-\frac{\partial f}{\partial L_{\text {out }}} \frac{\partial L_{\text {out }}}{\partial P}}{\frac{\partial f}{\partial h}+\frac{\partial f}{\partial L_{\text {out }}} \frac{\partial L_{\text {out }}}{\partial h_{L}}}$ & \\
&
\end{tabular}

Source: Authors.

Table 3 - Derivative terms of the process model.

\begin{tabular}{c|c}
$\frac{\partial f}{\partial h}=(D-2 \bar{h}) \frac{\bar{L}_{\text {in }}-\bar{L}_{\text {out }}}{2 C} \bar{u}^{-\frac{3}{2}}$ & $\frac{\partial L_{\text {out }}}{\partial h_{L}}=\frac{2.4 \times 10^{-4} e^{\overline{x_{L}}} C_{v}}{2\left(\rho_{f}^{0.5}\right)}\left(P+\rho_{L} g \bar{h} \times 10^{-5}-P_{1}\right)^{-0,5} \times \rho_{L} g \times 10^{-5}$ \\
\hline$\frac{\partial f}{\partial L_{\text {in }}}=\frac{1}{2 C \sqrt{(D-\bar{h}) \bar{h}}}$ & $\frac{\partial L_{\text {out }}}{\partial x_{L}}=2.4 \times 10^{-4} e^{\overline{x_{L}}} C_{v} \sqrt{\frac{\bar{P}-P_{1}}{\rho_{f}}}$ \\
\hline$\frac{\partial f}{\partial L_{\text {out }}}=\frac{-1}{2 C \sqrt{(D-\bar{h}) \bar{h}}}$ & $\frac{\partial L_{\text {out }}}{\partial P}=\frac{2.4 \times 10^{-4} e^{\overline{x_{L}}} C_{v}}{\sqrt{\rho_{f}\left(\bar{P}-P_{1}\right)}}$
\end{tabular}

Source: Authors.

\subsection{Process control and model validation}

Operational data set of a real production facility, including the liquid level, control valve position and outlet flow rate information of an actual horizontal separator, described in Table 4, were used for linear model validation, and outputs values comparison. 
Research, Society and Development, v. 10, n. 4, e55010414397, 2021

(CC BY 4.0) | ISSN 2525-3409 | DOI: http://dx.doi.org/10.33448/rsd-v10i4.14397

Table 4 - Horizontal separator main dimensions and operating conditions.

\begin{tabular}{r|c|c}
\hline Length $-\mathrm{C}:$ & 7.980 & $\mathrm{M}$ \\
\hline Diameter $-\mathrm{D}:$ & 2.235 & $\mathrm{M}$ \\
\hline Flow coefficient of the liquid control & 73 & - \\
\hline Flow coefficient of gas control & 70 & - \\
\hline OLUID PROPERTIES density - dens_f: & 830 & $\mathrm{~kg} / \mathrm{m}^{3}$ \\
\hline Gas molecular weight: & 0.021 & $\mathrm{~kg} / \mathrm{mol}$ \\
\hline STATIONARY STATE VALUES OF THE PVs \\
\hline Pressure: & 1.300 & $\mathrm{M}$ \\
\hline Temperature: & 303.15 & $\mathrm{Bar}$ \\
\hline LV position: & 0.309 & - \\
\hline PV position: & 0.5 & - \\
\hline Liquid inlet/outlet flow rate: & $300 / 300$ & $\mathrm{~m}^{3} / \mathrm{day}$ \\
\hline Gas inlet/outlet flow rate: & $74000 / 74000$ & $\mathrm{~m}^{3} / \mathrm{day}$ \\
\hline LV downstream pressure (2 ${ }^{\text {nd }}$ stage & 2.5 & Bar \\
\hline PV downstream pressure (gasline & 6.5 & Bar
\end{tabular}

Source: Authors.

For model validation, an open loop scheme shown in Figure 2 was used in Simulink ${ }^{\circledR}$ for comparing model outputs with real data. With the same intention closed loop scheme in Figure 3 has been developed.

Figure 2 - Model validation block diagram.



Source: Authors. 
Figure 3 - Level control block diagram for the horizontal separator using GSC.



Source: Authors.

A calculation routine was prepared in Matlab ${ }^{\circledR}$ to perform all calculations presented in the methodology for a set of inputs parameters and expected disturbs. These calculations were necessary to feed data to the model.

\subsection{Performance indexes}

In order to quantify the performance attained in the simulations, the following index were used: Integral Absolute Error (IAE), Integral Squared Error (ISE), Integral Time-weighted Absolute Error (ITAE) and Integral Time-weighted Squared Error (ITSE) defined as stated in Equations from 9 to 12 (Ogunnaike \& Ray, 1994). Control Effort (CE), Equation 13, have been defined as proposed in Bartys and Hryniewicki (2019).

$I A E=\int_{0}^{\infty}|\varepsilon(t)| d t$

$I S E=\int_{0}^{\infty} \varepsilon^{2}(t) d t$

$\operatorname{ITAE}=\int_{0}^{\infty} t|\varepsilon(t)| d t$

ITSE $=\int_{0}^{\infty} t \varepsilon^{2}(t) d t$

$C E=\frac{1}{t} \frac{1}{\Delta x_{L}} \int_{0}^{t}\left|\frac{d x_{L}(t)}{d t}\right| d t$

In the above equations the upper integral limit has been replaced by the simulation duration time.

\section{Results and Discussion}

\subsection{Model validation}

Analysis of the control valve output flow rate against its opening position has indicated that the internal plug and cage assembly has exponential flow pattern as measured for several operational points with results in Figure 4. 
Figure 4 - Actual control valve output flow curve.



Source: Authors.

Based on experimental results, Equation 5 must have to be updated to Equation 14 in order to reflect the real control valve flow curve pattern. Thus, partial derivatives $\frac{\partial L o u t}{\partial h L}, \frac{\partial L o u t}{\partial x L}$ and $\frac{\partial L o u t}{\partial P}$ were also modified to Equation 15 to 17 , respectively.

$$
L_{\text {out }}(t)=0,0438 \times 10^{-4} \times e^{3,73 x_{L}} \times C_{v} \sqrt{\frac{\Delta P}{\rho_{f}}}
$$

$\frac{\partial L_{\text {out }}}{\partial h_{L}}=\frac{0,0438 \times 10^{-4} e^{3,73 \overline{x_{L}}} C_{v}}{2\left(\rho_{f}^{0,5}\right)}\left(\bar{P}+\rho_{L} g \bar{h} \times 10^{-5}-P_{1}\right)^{-0,5} \times \rho_{L} g \times 10^{-5}$

$\frac{\partial L_{\text {out }}}{\partial x_{L}}=0,1634 \times 10^{-4} e^{3,73 \overline{\bar{x}_{L}}} C_{v} \sqrt{\frac{\bar{P}+\rho_{L} g \bar{h} \times 10^{-5}-P_{1}}{\rho_{f}}}$

$\frac{\partial L_{\text {out }}}{\partial P}=\frac{0,0438 \times 10^{-4} e^{3,73 \overline{\bar{x}_{L}}} C_{v}}{2 \sqrt{\rho_{f}\left(\bar{P}+\rho_{L} g \bar{h} \times 10^{-5}-P_{1}\right)}}$

For the conditions informed in Table 4, the controller was changed to manual mode and the valve position changed from $0.309 \mathrm{~m}$ to 0.255 in attempt to validate the horizontal separator modeling, and the results plotted in Figure 5. With similar objective, tests in closed loop were also carried out and compared to simulated output values for the same input conditions, and the results are shown in Figures 6 and 7.

Figure 5 - Open loop model validation test.

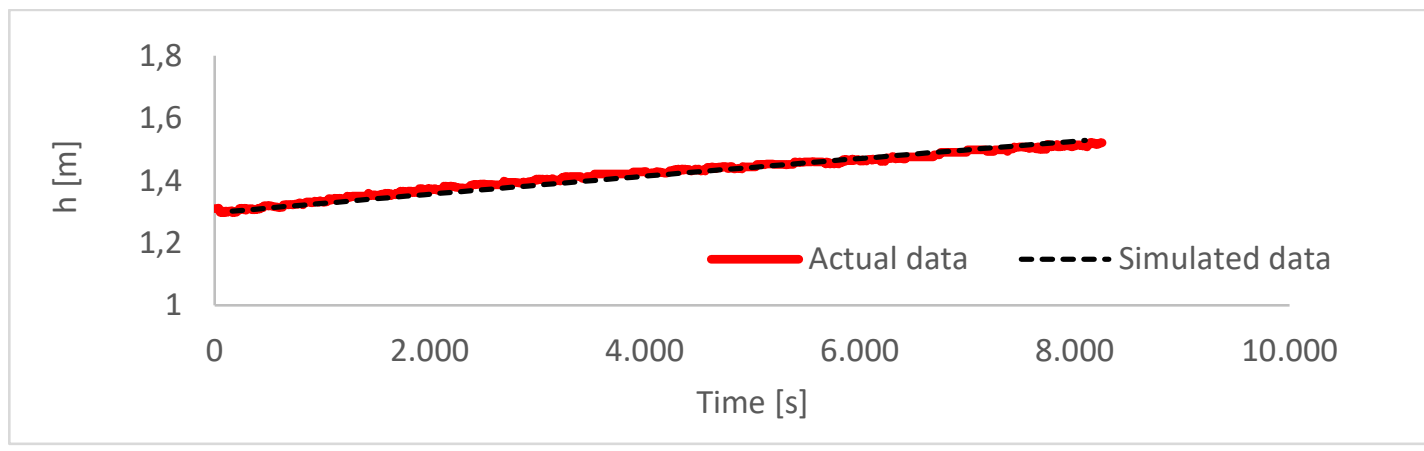

Source: Authors. 
Figure 6 - Closed loop model validation test. $K_{c}=2, T_{i}=10 s, T_{d}=2 s$.

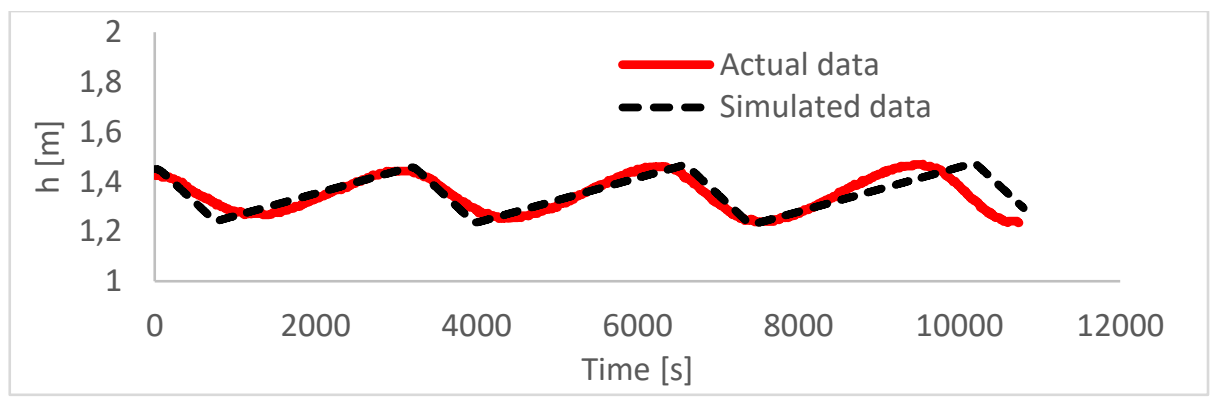

Source: Authors.

Figure 7 - Closed loop model validation test. $K_{c}=4, T_{i}=6 s, T_{d}=1.5 s$.

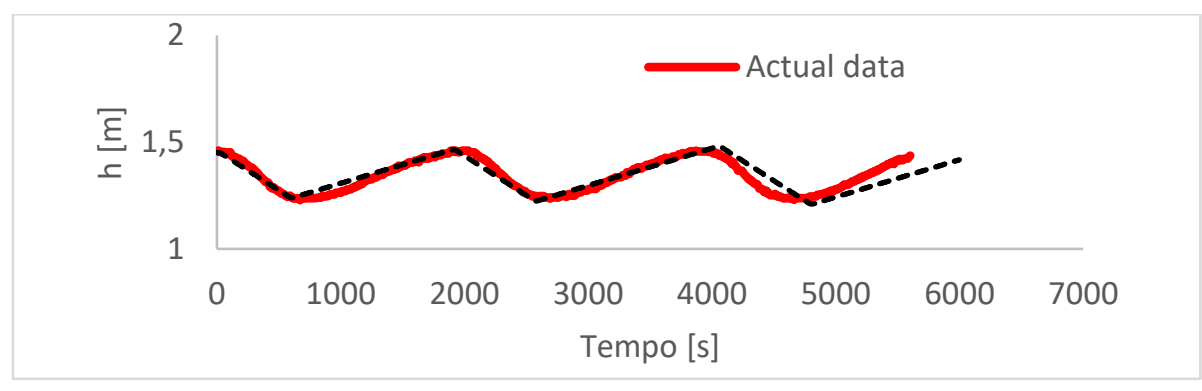

Source: Authors.

As can be seen in Figures 5, 6 and 7, the model can adequately represent liquid level dynamic in a horizontal separator considering both open and closed loop control system, respectively. Then, the proposed model was used to evaluate the gain scheduling control performance against a linear PI control law.

\subsection{Gain Scheduling Control (GSC)}

Application of the data set to the model has revealed non-linearity behavior in the model regarding the liquid level $(h)$ and strongly due to valve position $\left(x_{L}\right)$. To develop the GSC control law, the operational space for liquid level $h$ and valve position $x_{L}$ was divided into eight intervals generating an $8 \times 8$ matrix. For each combination pair $\left(h, x_{L}\right)$, the static process gain and time constants were calculated generating the results in Tables 5 and 6 , respectively.

Table 5 - Static process gain values.

\begin{tabular}{|c|c|c|c|c|c|c|c|c|c|}
\hline \multicolumn{10}{|c|}{$K_{p 2}$} \\
\hline & & \multicolumn{8}{|c|}{$h[m]$} \\
\hline & & 1.250 & 1.329 & 1.407 & 1.486 & 1.564 & 1.643 & 1.721 & 1.800 \\
\hline \multirow{8}{*}{$x_{L}[0-1]$} & 0.1000 & 421.68 & 422.27 & 422.86 & 423.44 & 424.03 & 424.61 & 425.20 & 425.79 \\
\hline & 0.2143 & 421.68 & 422.27 & 422.86 & 423.44 & 424.03 & 424.61 & 425.20 & 425.79 \\
\hline & 0.3286 & 421.68 & 422.27 & 422.86 & 423.44 & 424.03 & 424.61 & 425.20 & 425.79 \\
\hline & 0.4429 & 421.68 & 422.27 & 422.86 & 423.44 & 424.03 & 424.61 & 425.20 & 425.79 \\
\hline & 0.5571 & 421.68 & 422.27 & 422.86 & 423.44 & 424.03 & 424.61 & 425.20 & 425.79 \\
\hline & 0.6714 & 421.68 & 422.27 & 422.86 & 423.44 & 424.03 & 424.61 & 425.20 & 425.79 \\
\hline & 0,7857 & 421.68 & 422.27 & 422.86 & 423.44 & 424.03 & 424.61 & 425.20 & 425.79 \\
\hline & 0.9000 & 421.68 & 422.27 & 422.86 & 423.44 & 424.03 & 424.61 & 425.20 & 425.79 \\
\hline
\end{tabular}

Source: Authors. 
Table 6 - Time constant values.

$\tau_{p 2} \times 10^{6}[s]$

\begin{tabular}{|c|c|c|c|c|c|c|c|c|c|}
\hline & & \multicolumn{8}{|c|}{$h[m]$} \\
\hline & & 1.250 & 1.329 & 1.407 & 1.486 & 1.564 & 1.643 & 1.721 & 1.800 \\
\hline \multirow{8}{*}{$\begin{array}{l}x_{L}[0 \\
-1]\end{array}$} & 0.1000 & 1.8318 & 1.8129 & 1.7842 & 1.7454 & 1.6956 & 1.6339 & 1.5587 & 1.4679 \\
\hline & 0.2143 & 1.1960 & 1.1837 & 1.1650 & 1.1396 & 1.1071 & 1.0668 & 1.0177 & 0.9584 \\
\hline & 0.3286 & 0.7809 & 0.7729 & 0.7607 & 0.7441 & 0.7229 & 0.6966 & 0.6645 & 0.6258 \\
\hline & 0.4429 & 0.5099 & 0.5046 & 0.4967 & 0.4858 & 0.4720 & 0.4548 & 0.4339 & 0.4086 \\
\hline & 0.5571 & 0.3329 & 0.3295 & 0.3243 & 0.3172 & 0.3082 & 0.2970 & 0.2833 & 0.2668 \\
\hline & 0.6714 & 0.2174 & 0.2151 & 0.2117 & 0.2071 & 0.2012 & 0.1939 & 0.1850 & 0.1742 \\
\hline & 0.7857 & 0.1419 & 0.1405 & 0.1382 & 0.1352 & 0.1314 & 0.1266 & 0.1208 & 0.1137 \\
\hline & 0.9000 & 0.0927 & 0.0917 & 0.0903 & 0.0883 & 0.0858 & 0.0827 & 0.0789 & 0.0743 \\
\hline
\end{tabular}

Source: Authors.

Tuning method adopted in this paper was the Internal Model Control (IMC) which for a FOP proposes a PI with gains according to [24] and represented in Equations 18 and 19.

$K_{c}=\frac{\tau_{p}}{K_{p} \times \lambda}$

$T_{i}=\tau_{p}$

The parameter $\lambda$ is the performance criteria of the IMC tuning procedure and defines how fast the process output tracks the setpoint Bartys and Hryniewicki (2019). It's recognizable that the closed loop containing $G_{2}(s)$, along with controller FT, $G_{C}$, defines a second order system, Equation 20.

$G_{M F}=\frac{K_{\text {range }} G_{C}(s) G_{2}(s)}{1+K_{\text {rangeL }} G_{C}(s) G_{2}(s)}=\frac{T_{i} s+1}{\frac{T_{i} T_{p 2}}{K_{\text {rangeL }} K_{c} K_{p 2}} s^{2}+\left(T_{i}+\frac{T_{i}}{K_{\text {rangeL }} K_{c} K_{p 2}}\right) s+1}$

The system of Figure 4 has been simulated, with a 5\% SP step input, for $\lambda=30,90,270,810 \mathrm{~s}$. Results indicates that to $\lambda=90,270,810 s$ the system is underdamped. For $\lambda=30 s$, a damping ratio, $\xi=1,23$ is achieved and, since oscillation induction is not meant by the controller, this $\lambda$ value was chosen. Lower $\lambda$ value, say it 10 seconds, are not recommended because it generates huge values for $K_{c}$ which in turn causes unnecessary control effort and even, eventually, instabilities in the presence of noises.

Considering $\lambda$ equal to 30 seconds, the $K_{c}$ matrix can be found as in Table 7. Based on IMC method rules, very large $T_{i}$ values were observed and, as a compromising solution, the values of the interpolation is divided by a factor of $10^{3}$, still resulting in integral action observation (offset removal of the permanent response). 
Table 7 - Proportional scheduling gain.

$\mathrm{Kc}\left(\mathrm{m}^{-1}\right)$

\begin{tabular}{|c|c|c|c|c|c|c|c|c|c|}
\hline & & \multicolumn{8}{|c|}{$\mathrm{h}[\mathrm{m}]$} \\
\hline & & 1.250 & 1.329 & 1.407 & 1.486 & 1.564 & 1.643 & 1.721 & 1.800 \\
\hline \multirow{8}{*}{$\mathrm{x}_{\mathrm{L}}[0-1]$} & 0.1000 & 144.80 & 143.10 & 140.65 & 137.40 & 133.29 & 128.26 & 122.19 & 114.91 \\
\hline & 0.2143 & 94.54 & 93.44 & 91.83 & 89.71 & 87.03 & 83.74 & 79.78 & 75.03 \\
\hline & 0.3286 & 61.73 & 61.01 & 59.96 & 58.57 & 56.82 & 54.68 & 52.09 & 48.99 \\
\hline & 0.4429 & 40.31 & 39.83 & 39.15 & 38.24 & 37.10 & 35.70 & 34.01 & 31.98 \\
\hline & 0.5571 & 26.32 & 26.01 & 25.56 & 24.97 & 24.22 & 23.31 & 22.20 & 20.88 \\
\hline & 0.6714 & 17.18 & 16.98 & 16.69 & 16.30 & 15.81 & 15.22 & 14.50 & 13.63 \\
\hline & 0.7857 & 11.22 & 11.09 & 10.90 & 10.64 & 10.32 & 9.93 & 9.46 & 8.90 \\
\hline & 0.9000 & 7.32 & 7.24 & 7.11 & 6.95 & 6.74 & 6.48 & 6.18 & 5.81 \\
\hline
\end{tabular}

Table 8 - Proportional scheduling gain.

$\mathrm{Ti}(\mathrm{s})$

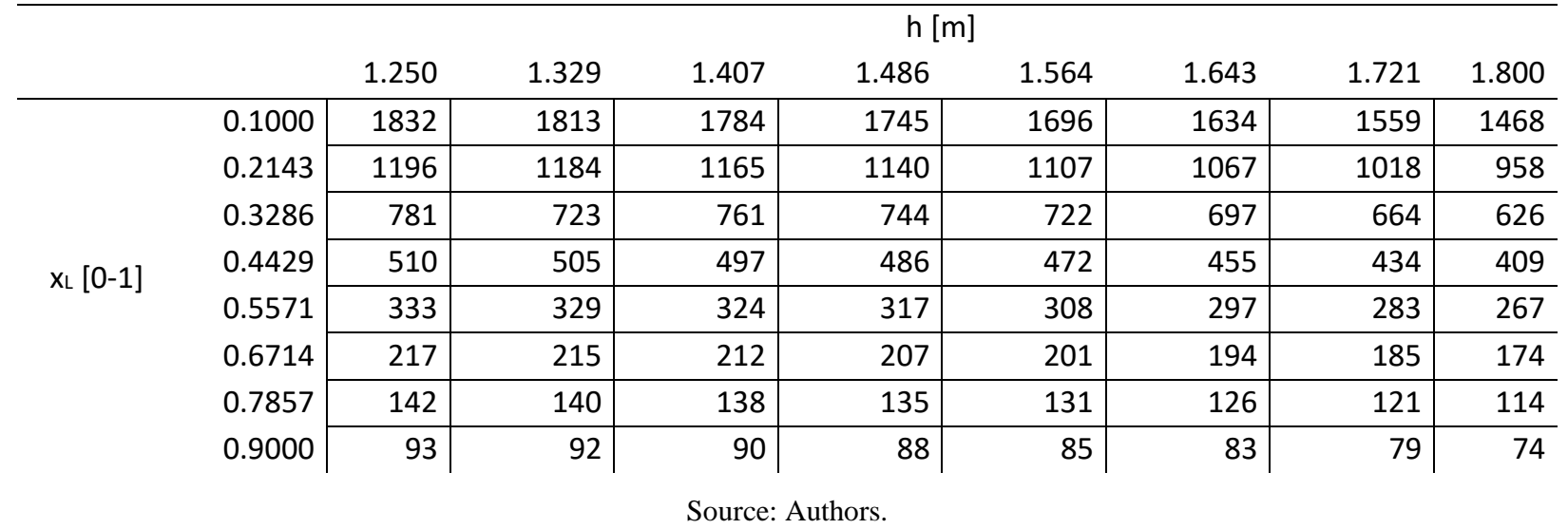

In order to allow GSC implementation, data in Table 7 and 8 were interpolated using a 3x3 polynomial fit curve function in MATLAB ${ }^{\circledR}$ for both PI controller parameters. The interpolation polynomials found using this data set are presented by Equations 21 and 22 for $K_{c}$ and $T_{i}$, respectively. In both interpolations the coefficients has $95 \%$ confidence bounds with $r^{2}=$ $0,9996$.

$$
\begin{aligned}
& K c=168.7+65.75 h-643.9 x_{L}-19.93 h^{2}-87.64 h x_{L}+854.3 x_{L}^{2}-10.19 h^{3}+81.45 h^{2} x_{L}-101,7 h x_{L}^{2} \\
&- 298,4 x_{L}^{3} \\
& T i=2084+ 865.2 h-8019 x_{L}-237.6 h^{2}-1243 h x_{L}+10770 x_{L}^{2}-135.4 h^{3}+1049 h^{2} x_{L}-1237 h x_{L}^{2} \\
&-3792 x_{L}^{3}
\end{aligned}
$$

\subsection{GSC simulation and comparison}

For further simulations, the non-linear model described in Table 1 was used. Some disturbs were performed on setpoint values (servo control) and inlet liquid flow rate (regulatory control). The stationary state and input conditions are presented in

Tables 9 and 10. PI conventional controller have been tuned for middle operation point of the separator vessel, $\bar{L}_{i n}=500 \frac{m^{3}}{d a y}$, 
$\bar{h}=1,325 m, \bar{x}_{L}=0,53$, which returns as gains, $K_{c}=28.8$ and $T_{i}=364,8 \mathrm{~s}$. These parameters remained fixed for this controller through all simulations.

Table 9 - Stationay states and input conditions for the servo problem.

\begin{tabular}{c|c|c|c|c|c|c|c} 
Simu. & $\bar{L}_{\text {in }}\left[\frac{m^{3}}{\text { day }}\right]$ & $\bar{L}_{\text {in }}\left[\frac{m^{3}}{s}\right]$ & $\bar{x}_{L}$ & $\bar{h}[\mathrm{~m}]$ & $\Delta h[\%]$ & $\Delta t[s]$ & $t[s]$ \\
\hline$\# 1$ & 100 & 0.00115 & 0.0400 & 1.25 & {$[+1,60+3,20+1,60-0,80-4,00]$} & 3800 & 24000 \\
\hline$\# 2$ & 350 & 0.00405 & 0.4500 & 1.40 & {$[+3,57+1,43+4,29+0,71-2,14]$} & 3600 & 24000
\end{tabular}

Source: Authors.

Table 10 - Stationay states and input conditions for the servo problem.

\begin{tabular}{c|c|c|c|c|c|c|c} 
Simu. & $\bar{L}_{\text {in }}\left[\frac{m^{3}}{\mathrm{dia}}\right]$ & $\bar{L}_{\text {in }}\left[\frac{\mathrm{m}^{3}}{\mathrm{~s}}\right]$ & $\bar{x}_{L}$ & $\bar{h}[\mathrm{~m}]$ & $\Delta L_{\text {in }}\left[\frac{\mathrm{m}^{3}}{\mathrm{dia}}\right]$ & $\Delta t[s]$ & $t[s]$ \\
\hline$\# 3$ & 600 & 0,00694 & 0,6000 & 1,35 & {$[-300-200-10050]$} & 5000 & 24000 \\
\hline$\# 4$ & 900 & 0,01042 & 0,6000 & 1,30 & {$[-300-500-600-400]$} & 4000 & 24000
\end{tabular}

Source: Authors.

The results of the simulations can be seen in Figures 8 to 11 while the performance indexes can be found in Table 11 below. Gain adaptation of GSC, presented only for simulation \#1 is showed in the Figure 12.

Table 11 - Performance Indexes.

\begin{tabular}{c|c|c|c|c|c|c} 
Simulation & Controller & IAE & ISE & ITAE & ITSE & CE \\
\hline \multirow{2}{*}{$\# 1$ (servo) } & GSC & 93.70 & 1.0700 & 1100981 & 13002 & 0.0671 \\
\cline { 2 - 7 } & PI CONV & 113.30 & 1.4700 & 1316722 & 17867 & 0.0688 \\
\hline \multirow{2}{*}{$\# 2$ (servo) } & GSC & 101.32 & 3.4787 & 1324374 & 50510 & 0.1100 \\
\cline { 2 - 7 } & PI CONV & 94.32 & 3.4369 & 1227172 & 50139 & 0.1178 \\
\hline \multirow{2}{*}{$\# 3$ (regulatory) } & GSC & 17.14 & 0.0751 & 182613 & 832.8 & 0.0171 \\
\cline { 2 - 7 } & PI CONV & 17.34 & 0.1071 & 184386 & 1173.0 & 0.0197 \\
\hline \multirow{2}{*}{$\# 4$ (regulatory) } & GSC & 13.72 & 0.0534 & 165575 & 651.5 & 0.0138 \\
\cline { 2 - 7 } & PI CONV & 13.83 & 0.0566 & 166526 & 677.5 & 0.0146
\end{tabular}

Source: Authors. 
Research, Society and Development, v. 10, n. 4, e55010414397, 2021

Figure 8 - Simulation \#1 - servo problem.
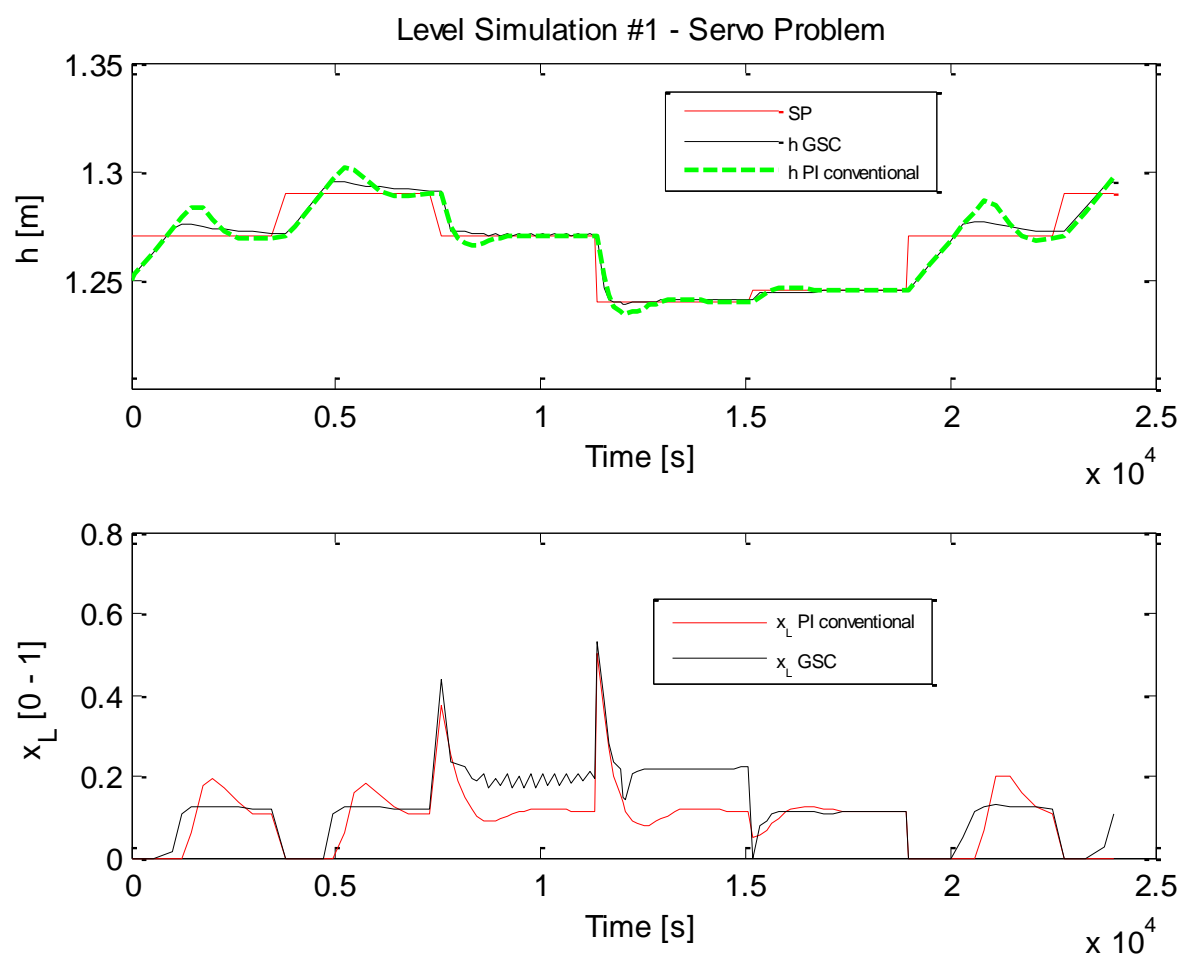

Source: Authors.

Figure 9 - Simulation \#2 - servo problem.
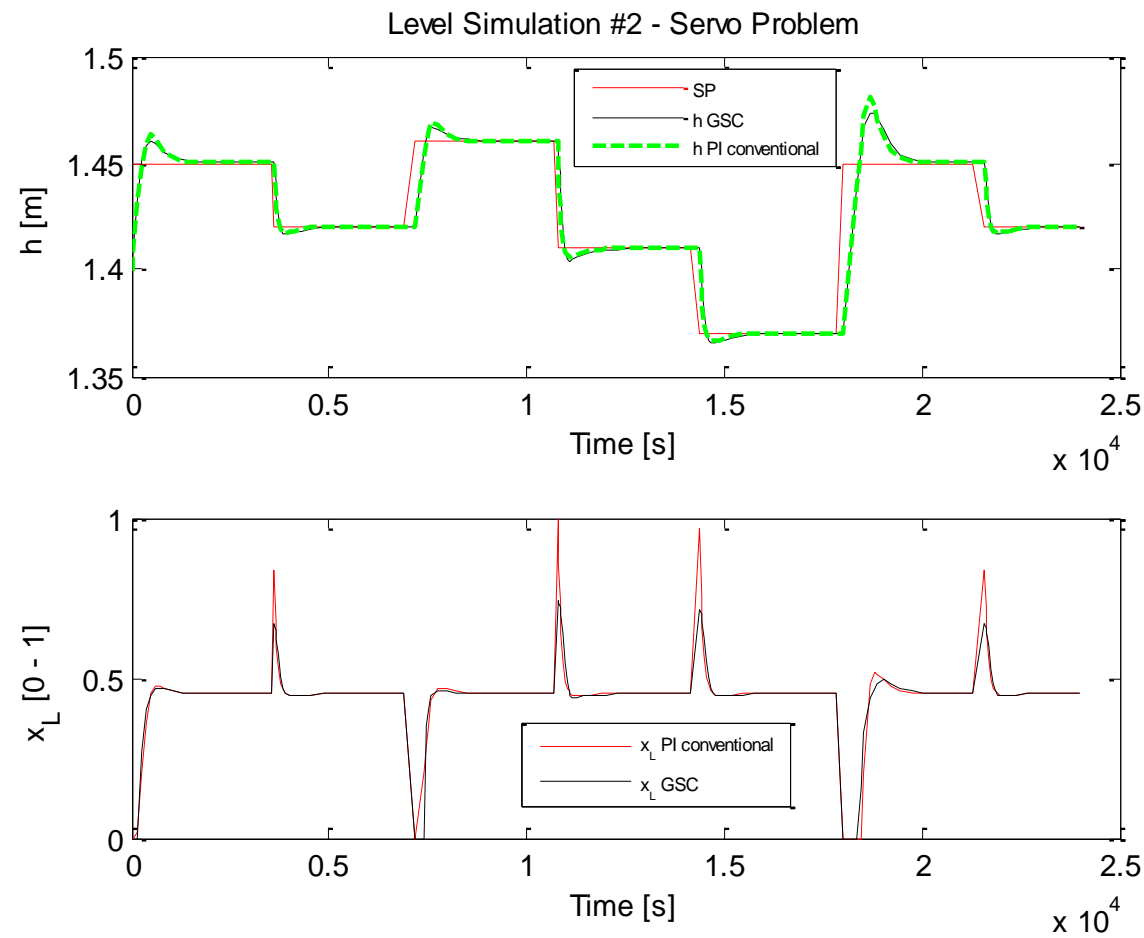

Source: Authors. 
Figure 10 - Simulation \#3 - regulatory problem.


Source: Authors.

Figure 11 - Simulation \#4 - regulatory problem.


Source: Authors. 
Figure 12 - Gain Scheduling gains compared to conventional PI gains for simulation \#1.


Source: Authors.

\subsection{Results analysis}

The comparison of model versus actual data set has been considered satisfactory for both open and closed loop cases. Major non-linearities found for the level dynamics were the level itself and specially the valve flow curve with exponential feature. Users of the linearized model (Figure 3) must have in mind the intrinsic limitations of the mathematical modeling because the transfer functions are determined based in the model linearization in the stationary point so steps in disturbs of liquid load flow rate or level setpoint must be applied in thick steps. Time constants are the same for $G_{1}(s), G_{2}(s)$ and $G_{3}(s)$ with high magnitude (many hours) and similar value were observed in Zhenyu, Michael and Løhndorf (2010). This way, any attempt of system identification like step response were not feasible because, for any practical observation window, the system looked like a pure capacitive system. Analyzing actual data sets it was not detected dead time and so not included in the model.

Pressure dynamics are much orders of magnitude faster than level dynamics. Allied with an existing pressure loop control system, fluctuations of this variable in practice have shown neglectable interference with level.

To the Integral time $T_{i}$, a dividing factor of 1000 have been applied. IMC recommended values, equal to the time constant, would result in a Proportional (P) controller instead of Proportional-Integral (PI). With such adjustment integral action had very smooth action allowing offset removal after stabilization time.

The non-linear model, as stated in Table 1, was implemented in SIMULINK. Simulations were carried out for setpoint step changes and inlet flow rate for both Gain Scheduling Control (GSC) and standard PI controller. GSC had better results for all simulations. The indexes for simulation \#2 were better for conventional PI but, due to control valve saturation at $100 \%$ opened, this controller was reproved for this operational condition since, with $x_{L}=1$, an output flowrate, $L_{\text {out }}=2825 \frac{\mathrm{m}^{3}}{\text { dia }}$, well above 
the inline flowmeter and downstream equipment maximum acceptable flowrate is reached. Also sharp changes in the Manipulated Variable (MV), $L_{\text {out }}$, cause operational problems like gas flashing due to pressure transients and flow turbulences.

GSC adaptation is very clear at Figure 12 and is the reason why the actuator respond properly for any position inside the equipment operational values,

\section{Conclusion}

Although apparently standard PI may indicate as good performance as GSC based on the Table 11, the nature of the strong non-linear control valve makes impossible a fixed parameter controller work efficiently in all control loop operational range. GSC has get better performance with reductions up to $17,65 \%$ for IAE, $29,88 \%$ for ISE, 16,38\% for ITAE, $29,00 \%$ for ITSE and 13,20\% for Control Effort (CE). As conclusion, in order to achieve efficient control with stability, avoiding control valve saturation and still having a smooth outlet flow rate, GSC is the choice despite simplicity of the standard PI controller.

\section{References}

Arnold, K. \& Stwart, M. (2010). Surface Production Operations. GPP.

Bagyaveereswaran, V. \& Arulmozhivarman, P. (2019). Gain Scheduling of a Robust Setpoint Tracking Disturbance Rejection and Aggressiveness Controller for a Nonlinear Process. Processes/MDPI.

Ban, X. \& Wu, F. (2015). Gain scheduling output feedback control of linear plants with actuator saturation. ELSEVIER, ScienceDirect, Journal of the Franklin Institute.

Bartys, M. \& Hryniewicki, B. (2019). The Trade-Off between the Controller Effort and Control Quality on Example of an Electro-Pneumatic Final Control Element. Actuators / MDPI.

Basçi, A. \& Derdiyok, A. (2016). Implementation of an adaptive fuzzy compensator for coupled tank liquid level control system. Elsevier, ScienceDirect, Measurement.

Bisowarno, B. H., Tian, Y. M. \& Tadé, O. (2003). Model Gain Scheduling Control of an Ethyl tert-Butyl Ether Reactive Distillation Column. Ind. Eng. Chem. Res. 2003, 42, 3584-3591

Cellier, F. E. \& Kofman, E. (2006). Continuous System Simulation. SPRINGER.

David, C. \& Lei, W. (2005). Experimental evaluation of adaptive three-tank level control. ISA Transactions 44 2005! $283-293$.

Fernandes, L. S. L., Moraes, F. F. C., Paulo, J. B. A. \& Oliveira, J. A. (2013). Gain scheduling adaptive control applied to a particular mixer-settler equipment. ELSEVIER, Control Engineering Practice.

Gao, Y., Lakerveld, R. (2019). Gain scheduling PID control for directed self-assembly of colloidal particles in microfluidic devices. Process systems engineering.7

Giovani, N. (2004). Controle por bandas: conceitos básicos e aplicação no amortecimento de oscilações de carga em unidades de produção de petróleo. Bol. Téc. Petrobras, Rio de Janeiro, 47 (2/4): 151 - 165, abr./dez.

John-Morten, G., Stig, S., \& Gunleiv, S. (2005). Increased oil production by advanced control of receiving facilities. ELSEVIER, IFAC Proceedings Volumes, Volume 38, Issue 1, p. 567-572.

Koche, J. C. (2011). Fundamentos de metodologia científica. Vozes.

Leosirikul, A., Chilin, D., Liu, J., Davis, J. F. \& Christofides P. D. (2011). Monitoring and retuning of low-level PID control loops. ELSEVIER Chemical Engineering Science.

Giovani, N., Medeiros, J. L. \& Araújo, O. Q. F. (2010). Modelagem e controle na produção de petróleo. São Paulo: BLUCHER.

Ogunnaike, B. A. \& Ray, W. H. (1994). Process Dynamics, Modeling and Control. Oxford Unity Press.

Onat, C. (2014). WGC Based Robust and Gain Scheduling PI Controller Design for Condensing Boilers. ResearchGate.

Sarkar, R. \& Banerjee, A. (2019). An IMC-PI based Level Control with Gain Scheduling and Set Point Weighting. International Conference on Electrical, Electronics and Computer Engineering (UPCON), p. 1-6, ALIGARH, India.

Sausen, A., Sausen, P. S., Reimbold, M. \& Campos, M. (2012). Application and comparison of level control strategies in the slug flow problem using a mathematical model of the process. Acta Scientiarum.

Sayda, A.F. \& Taylor, J.H. (2007). Modeling and control of three-phase gravity separators in oil production facilities. In Proc. of 2007 American Control Conference, pages 4847-4853, July 2007. 
Research, Society and Development, v. 10, n. 4, e55010414397, 2021

(CC BY 4.0) | ISSN 2525-3409 | DOI: http://dx.doi.org/10.33448/rsd-v10i4.14397

Seborg, Edgar, Mellichamp \& Doyle. (2011). Process Dynamics and Control. WILLEY, (3th ed.).

Sundaram, U. M. (2013). Level Control of Horizontal Cylindrical Tank Using Intelligent Control Techniques. Proceedings of the International Conference on Trends in Industrial Measurements and Automation (TIMA-2013), Department of Instrumentation Engineering, MIT Campus, Anna University, Chennai-44.

Suryawanshi, P., Chandrashekhar, P. \& Virendra, K. S. (2007). A Gain Scheduling Approach for Control of Non-linear Level Process. ational Systems Conference, Manipal, India.

Vikhe, P., Parvat, B. J. \& Kadu, C. B. (2019). Design of Tank Level system using Gain Scheduling Controller. International Journal of Information and Computing Science, Volume 5, Issue 9, September 2018. ISSN NO: 0972-1347.

Zaher, A. A. (2018). Design of Model-Based Gain Scheduling Controllers for Nonlinear Systems. Journal of Physics: Conference Series.

Zhenyu, Y., Michael, J. \& Løhndorf B. (2010). On the Innovation of Level Control of an Offshore Three-Phase Separator. Proceedings of the 2010 IEEE International Conference on Mechatronics and Automation, August 4-7, 2010, Xi'an, China. 